\title{
Commentary
}

\section{The Value of Inequality}

\author{
Gustaaf Bos $^{1, *}$ and Doortje Kal ${ }^{2}$ \\ ${ }^{1}$ Department of Medical Humanities, VU University Medical Centre/EMGO+, 1081 HV Amsterdam, The Netherlands; \\ E-Mail: g.bos@vumc.nl \\ ${ }^{2}$ National Support Centre Kwartiermaken, 1091 BD Amsterdam, The Netherlands; E-Mail: d.kal@kwartiermaken.nl \\ * Corresponding author
}

Submitted: 19 June 2016 | Accepted: 19 July 2016 | Published: 10 November 2016

\begin{abstract}
Over the last two decades, inclusion and participation have become leading policy concepts within the Dutch chronic care and social welfare sector. People with an intellectual or psychiatric disability ought to get a chance to participate in, and belong to, the mainstream of our society-on the basis of equality and equivalence. Although on an international level this pursuit has been going on for at least five decades, it still raises all kinds of questions and debates. What does it mean if we want people with intellectual and/or psychiatric disabilities to participate in our society? Based on which idea(I)s about humanity do we define equality and equivalence? And by doing so, how much space is left for individual differences? In the following dialogue the two authors navigate the tension between similarity and difference in thinking about-and working towards-more space for marginalized people. In an attempt to withstand the contemporary dominance of equality thinking, marked by a strong focus on tenability and autonomy-and by extension an increasing climate of taboo around vulnerability and dependency-both authors stress the importance of recognizing and valuing difference, while discussing encounters between people with and without a severe intellectual and/or multiple disability.
\end{abstract}

\section{Keywords}

dependency; (in)equality; encounter; reflection; relational otherness; responsive ethics; severe intellectual and/or multiple disability; space for difference; suspension; vulnerability

\section{Issue}

This article is part of the issue "Humanity as a Contested Concept: Relations between Disability and 'Being Human'”, edited by Paul van Trigt (Leiden University, The Netherlands), Alice Schippers (Disability Studies in Nederland, The Netherlands) and Jacqueline Kool (Disability Studies in Nederland, The Netherlands).

(C) 2016 by the authors; licensee Cogitatio (Lisbon, Portugal). This article is licensed under a Creative Commons Attribution 4.0 International License (CC BY).

\section{Introduction}

Over the last two decades, inclusion and participation have become leading policy concepts within the Dutch chronic care and social welfare sector. Encouraged by various government documents and programs, people with an intellectual or psychiatric disability are no longer relegated to the margins of our society, but ought to get a chance to participate in and belong to its mainstreamon the basis of equality and equivalence (Ministerie van WVC, 1993; RMO, 2002; RVZ, 2002; Taskforce Vermaatschappelijking, 2002; Tweede Kamer, 1995). This rather drastic, idealistic and practical transformation of our chronic care and social welfare sector was legally founded in 2015, by means of four acts: the Community Support Act [Wet maatschappelijke ondersteuning], the Chronic Care Act [Wet langdurige zorg], the Participation Act [Participatiewet], and the Youth Act [Jeugdwet].

Although on an international level this pursuit has been going on for at least five decades, instigated by the appeal for normalization (Nirje, 1969) or social role valorization (Wolfensberger, 1983), it still raises all kinds of questions and debates. What does it mean if we want people with intellectual and/or psychiatric disabilities to participate in our society? What does this participation demand from both civilians with and without disabilities? 
How do (local) governments, institutions and companies relate to this? Based on which idea(I)s about humanity do we define equality and equivalence? And by doing so, how much space is left for individual differences?

In the following dialogue the two authors navigate the tension between similarity and difference in thinking about-and working towards-more space for marginalized people. The immediate reason for a joint publication on this topic is that Kal, while reading several drafts of Bos' dissertation on encounters in 'reversed integration' settings (formerly sheltered institutional sites where people without intellectual disabilities become neighbours of the original residents), sometimes felt dissatisfied about the way he framed and interpreted the position of difference, both in practices and in policy documents. This resulted in discomforting arguments and feelings of mutual alienation.

The authors chose to write this paper in the somewhat unorthodox form of an open, critical dialogue (see Abma, 2006; Smaling, 2008). A dialogue of this kind offers the opportunity to explain each of the authors' own perspectives before comparing them-through informative friction (see Kunneman, 2005) and intertwining (see Waldenfels, 1990)-in order to develop their thinking about working towards more space for difference.

The leading question, in their joint pursuit through these swampy lowlands (see Schön, 1987), is not so much which focus should be preferred-either similarity or difference-but mainly the possibility of one of those getting the upper hand. In an attempt to withstand the contemporary dominance of equality thinking, marked by a strong focus on tenability and autonomy-and by extension an increasing climate of taboo around vulnerability and dependency-both authors stress the importance of recognizing and valuing difference, while discussing encounters between people with and without a severe intellectual and/or multiple disability.

\section{Responding to Otherness}

Gustaaf Bos: I would like to start by saying a few things about the responsive character of our actions towards other people. According to the German phenomenologist Bernhard Waldenfels $(1990,2004)$ every single encounter with another person starts with an uncontrollable bodily response: we see, hear, smell, feel, or taste 'something' about the other, before this perception enters our consciousness. Waldenfels states that this preconscious, pre-reflexive perception of the other causes a confusing, conflicting experience, in which we are at once both connected with and separated from ourselves: our bodily self is responding while our consciousness is struggling to keep up. According to Waldenfels the 'something' to which our attention-preconsciously-turns is always that in which the other differs from us.

Waldenfels typifies this response to the otherness of the other as the nucleus of human behaviour. In doing so he rejects contemporary thinking about human interactions, in which the self is portrayed as an autonomous, rationally and individually acting agent. In Waldenfels' responsive phenomenology we do not decide a priori and/or on the basis of rational arguments how we will relate to another person, but first of all we undergo our body and that which triggers our senses, before we react (and reflect) consciously on that which touched us. It goes without saying that the aforementioned bodily response is everything but 'pure' or 'natural' - it is instead intertwined with our previous (learning) experiences and the contexts, people and cultures in which those experiences are embedded. This interdependency however, does not make our response any more controllable. Ergo: the otherness of the Other, in the sense of Lévinas (1969) - a concrete person in a physical, social, communal, cultural and historical context-puts me in motion before I know it.

Perceiving otherness is, according to Waldenfels, no neutral business, on the contrary: the otherness of the other might trigger and fascinate me as well as frighten and push me off. No matter how we subsequently react to this person, the unusual, the unfamiliar, the strange, attracts us and confuses us, disrupts us, puts us out of our comfort zone. During the fieldwork I did for my dissertation Responding to otherness [Antwoorden op andersheid $]^{1}$ (Bos, 2016), about what happens in encounters between neighbours with and without (severe) intellectual disabilities, I heard many personal stories about this confusion and disruption. The stories came from participants without intellectual disabilities, and depicted an experience that I frequently shared (Bos, 2016, pp. 61-67).

Waldenfels points out that we find it extremely difficult to let this confusing otherness be, to leave it alien. Many of us cannot accept that the difference between the other and ourselves is fundamentally unknowable. Often we equate this otherness and the other, and then stigmatize and try to avoid it. Even if we are indeed trying to connect with the other, we rather focus on shared characteristics and we usually do not pay attention to that which separates and confuses us (see Walmsley, 2001, 2004). However, by doing so we tend to-at least-lose sight of the otherness of the other, and-in the worst case-violate it (by means of romanticizing or ignoring it).

Mostly we do not seem to realize that the contemporary search for and identification of similarities and common ground between people with and without disabilities is only credible if everyone involved has the opportunity to contribute. At this point tension arises when it comes to people with a severe intellectual and/or multiple disability. How do we understand if there is some degree of mutual involvement in the search for what we share? To what extent are people with severe disabilities able to get involved in a search of any kind for that matter? How can we determine if there is any involvement and/or contribution? And which position and

\footnotetext{
${ }^{1}$ See English summary on http://dare.ubvu.vu.nl/handle/1871/53873
} 
meanings do we grant in this search to the personal differences, which are often perceived as more prominent than the similarities?

The responsive ethics from Waldenfels (2010)which stresses the recognition of the unknowable and inerasable differences between the other and ourselvesstrengthens my conviction that we should plead for more space for otherness. Specifically, the acknowledgment that the perspectives and life world of people with a severe intellectual disability-with whom verbal communication is (practically) impossible-are fundamentally unknowable for people without intellectual disabilities, forces us to give continuous thought to our responsibility for the way in which we attach form, content and meaning to how we respond to them. Why are we doing what we are doing? How much space do we-individually and as a society-offer persons with severe intellectual disabilities to manifest themselves? Which position are we willing to take in order to give them more space? And what form of relationship do we want?

Waldenfels' ethics taught me that, when I want to interpret my (inevitable, preconscious bodily) response to the otherness of the other, I have to acknowledge that this response refers primarily to myself, my familiar concept of man and worldview, my expectations, preferences and fears-in relation to the other. After all, in every part of my response to the demand of the other unfolds our relationship and the way I connect with the other. Thus my response is part of something that happens between us. There, literally between our bodies, is the leeway, the freedom we have; it is there we can shape our relationship. There, by means of my body, I can relate to the otherness, and try to do right by someone.

\section{A 'Passible’ Performance}

Doortje Kal: For some reason, the above-mentioned encouraged me to dig up an old abstract of a paper from my archive that my brother, philosopher Victor Kal, wrote: Jacques Derrida and messianity (Kal, 2004). I am particularly triggered by what you write about Waldenfels' recognition of the unknowable and inerasable character of the difference between the Other and ourselves. You argue that this unknowable and inerasable character of this difference forces us to give continuous thought to our responsibility for the way in which we shape our position towards the other, especially when it comes to people with a severe intellectual and/or multiple disability.

Perhaps I can even deepen this thought with Derrida. In my dissertation 'Setting up camp': Preparing a welcome for people with a psychiatric background [Kwartiermaken. Werken aan ruimte voor mensen met een psychiatrische achtergrond $]^{2}$ (Kal, 2001; see also Kal, 2012) I 'use' Derrida (1998), especially in the chapters on hospitality and on normative professionality.

Derrida's philosophy is labelled as 'deconstructionist thinking' and is thus related to postmodernism, whereby some define it as 'relativism'. Derrida passionately and persistently resists the accusations that in his work there is no space for responsibility, and that deconstructionism is irrelevant from a moral and political perspective. Insofar as deconstructionism generally aims to undo exclusion, it sticks with the emancipatory ideals of modernity!

However, in deconstructionist thinking the criterion or standard to which we measure or examine this emancipation is not considered to be at our disposal unthinkingly; rather it is about a justice that is not to be seen. As a consequence, we have to postpone the activist attitude that marks modernism. This encompasses a passive moment. At first, one cannot bring the new, or the otherness (the space for being other) to be by oneself, and certainly not just like that. In order to welcome difference, otherness, we have to first know how the other will feel welcomed. Inclusion, citizenship and participation do not seem to be adequate terms to make the people you refer to feel at home. However, neither do we feel at home with Wilfred, whom you describe in your dissertation (Bos, 2016, pp. 72-73), literally strapped to his bed-and in my opinion we should never feel at home in his situation.

Derrida says that a passive moment does not mean that deconstruction is without activity. In the last chapter of your dissertation you refer to this-following the Dutch philosopher Richard Brons (2014)-as a passible performance (Bos, 2016, p. 310; see Lyotard, 1988). A passible performance is a specific sensitivity to feel with, and respond to, the other-not aimed at bringing some kind of activity to this world, or even to rearrange it. Rather, the target of passibility is primarily to uncover the pretentious, apparently closed and definite character of texts and notions (and, I add: practices!) as being premature and not tenable. The effect of deconstruction lies in that the space which was sealed is made accessible. For what this space is made accessible stays open. The activity, which is produced by deconstruction, has a transient nature. The current norms are temporarily suspended, in order to find out whether or not they need a transformation or supplement. Meanwhile, the high justice-as far as I am concerned, the battle against exclusion, and working towards more inclusion, towards humanity-is not suspended. On the contrary: the aforementioned suspension of active involvement following certain norms takes place in the name of the latter. Or, as Derrida puts it: the given right is deconstructable, but justice is not.

For me, this means that your plea for space for otherness, your emphasis on our responsibility in the way in which we treat the other, is still in need of a more detailed interpretation-starting from this nondestructible justice.

Gustaaf Bos: Could you elaborate a little on this nondestructible high justice? I am especially interested in what defines whether or not something is constructible.

\footnotetext{
${ }^{2}$ See English summary on http://www.kwartiermaken.nl/english/summary-kwartiermaken-doortje-kal
} 
On what basis is this high justice immune for Derrida's deconstructionism?

Doortje Kal: As far as I am concerned your attemptlistening to the story of the illiterate other, who cannot speak but deserves to be heard-is an example of this higher justice. In the meantime, you demonstrate that the network of chronic care practice (and policy) needs deconstruction and reflection as well in order to facilitate a more valuable and righteous life for those who are unheard.

At this point I remember a remark that I made in the first chapter of my dissertation (Kal, 2001, p. 22), A question of difference, where I emphasize the tension which is given with the quest for the normalisation of the unknown, the alien (with 'normalisation' I refer here to ceasing the exclusion of 'the strange other'). Making this tension a central issue, I argue, always happens against a background of the eternal dilemma between a radical stand, which is doomed to stick in powerless purity versus a feasible activity that may compromise and whereby one-for the benefit of results-may concede what one is challenging. I then illustrate this with an example of me categorising people with a psychiatric background. Admittedly, such labelling might lead to stigmatization, but denying and moving past their otherness leads to exclusion as well. Ergo: it is about enduring this tension, about not avoiding it, but relating to it (see Boumans, 2013).

Gustaaf Bos: If I get what you mean, I think you now touch upon a paradox between 'thinking about' and 'working towards' space for marginalized people. If I focused solely on developing rational and cognitive knowledge, I would come to the conclusion that it is impossible to know the other, and thus to really make space for him. And, subsequently, this would lead me to believe that there is no point in trying to make more space. Therefore, we are in need of ideals and ethics.

If I understand you correctly, you advocate a deconstruction of current exclusionary structures, logics, and practices (à la Derrida), in order to create (temporal) open space for reconsidering the underlying norms. In this open space, we should-appealing to high justicereflect thoroughly on how we may contribute to the inclusion and participation of people who are different and extremely vulnerable.

Although I attach a high value to your aim and commitment, I also question your argumentation. In my view, an appeal to high justice regarding participation and inclusion is not self-evident. High justice may be undeconstructable, but the operationalisation of concepts and movements like inclusion and participation surely can be deconstructed.

Doortje Kal: Indeed, that is exactly my point!

Gustaaf Bos: And if the struggle against exclusion is awarded the predicate high justice, do you think there are other concepts and movements, which earn this predicate just as much?

Doortje Kal: Without a doubt! Human dignity maybe? We resist incarceration, isolation, strapping, because it is inhumane. We must keep looking for dignified alternatives.

\section{Striking Inequality}

Gustaaf Bos: Do not get me wrong, I do not intend to devalue the importance of societal hospitality and tolerance towards people who are different and extremely vulnerable. But I do claim that the way we-as a contemporary society, and as researchers and advocates of a more inclusive society-approach this pursuit, tends to evade the otherness and the lifeworld of people with a severe intellectual and/or multiple disability. By strongly emphasizing the similarities and communality, we are at risk of entrenching ourselves ever deeper in an unreflected presumption that the perspectives and ideals of people with an intellectual disability resemble those of people without disabilities. Moreover, that they all share our needs, dreams and motives. However, in doing so, we seem to forget about the striking differences in lifeworld and the asymmetrical positions of power (see Young, 1997).

Doortje Kal: At the same time, we should never dispute that they feel the need for a worthy life. However, what is dignified for them is not automatically clear to us. If people themselves are asking to be tied up, it is a real challenge to find worthy, 'desired' alternatives for them.

Gustaaf Bos: Amen. The confusion and alienation I often experienced during interactions with people with a severe intellectual or multiple disability in reversed integration settings - as well as my inability to attach satisfactory meanings to these encounters, in order to understand them somehow-made me critical towards the aforementioned emancipatory equality focus. Time and again I was astonished, enchanted, frightened, surprised and/or fascinated by so much otherness. During these encounters as well as afterwards, incomprehension and insecurity were reigning. Extraordinary experiences such as those I describe with Karel (Bos, 2016, pp. 139-140), Willem (p. 115) and Wilfred (pp. 72-73) made-and still make-me fundamentally doubt much of what hitherto was familiar to me. They forced me to question my view on man, my worldview, lifeworld, motives, expectations, and ideals - and thus changed my perspective on who I am. I could not help but recognise that all this prickly and provocative otherness cohered with my singularity, with who I was, with how I saw the world and myself.

Doortje Kal: Can you elucidate how? How did you see the world before and afterwards?

\section{Prickly, Relational Otherness}

Gustaaf Bos: I am glad you asked. These three encounters instigated an ever-growing doubt in me about the recognisability of the perspective of the other. I had begun my research with the intention of imagining the issues and worries of stakeholders with and without intellectual disabilities as correctly as possible-whether 
they could express themselves verbally or not. Due to my encounters with people like Karel, Willem and Wilfred it struck me that, as a researcher, I always performed from my own perspective. Although this perspective is inevitably shaped by interaction with others, I could never extract myself from it. Thus, I could never truly and fully represent another person's perspective. I would literally never be able to take the stand of another or walk in his shoes, simply because he is already (physically) in that position. And because Karel, Willem and Wilfred barely used verbal communication, I became more sensitive to the skewed power relations between them and meespecially in the academic and policy world, wherein words, sentences and texts are the mightiest machines to produce and spread knowledge that counts (see Deleuze \& Guattari, 1987; Jackson \& Mazzei, 2013). I could cope with those machines and have access to them; unlike Karel, Willem and Wilfred. This rendered me-and all verbally proficient people in their environment-a more powerful position than them.

If I was to say anything for a verbally non-proficient person, I could only do so when I kept an ongoing dialogue with him, in all modesty, respecting all doubts and through explaining my own motives and intentions.

The world and my position therein regarding other people became less manufacturable, less self-evident, and at the same time less open-ended than I assumed in the prelude to my doctoral research. At the start in 2010, I had been quite sure for instance that mutual encounters and connections potentially meant an improvement of anybody's quality of life. Subsequently I deemed interactions and relations between neighbours with and without intellectual disability desirable-and with my research I hoped to contribute to their (further) development. Throughout my two-and-a-half-year fieldwork however, I gradually reached the conclusion that I had failed to take the difficult, uncomfortable, painful and frightening aspects of difference sufficiently into account. For some stakeholders with an intellectual disability for instance, my sheer (often superficial and observing) presence appeared to be so threatening, that they responded to it by rejection or aggression, whereas others cowered frightfully every time I looked at them for a moment or greeted them while passing by. Because I had not spent any thought on the possibility of such undesirable encounters, which do not enrich the life of the people involved, but rather make them feel less happy, or even threaten their personality, I had failed to make enough space for the individual otherness of some stakeholders with an intellectual disability. I had falsely presumed that all the persons involved in my research would like to know the people in their neighbourhood sooner or later, because their life would benefit from it (Bos, 2016, p. 66).

My growing doubt about something I had deemed self-evident-i.e. not necessary to prove-before these encounters took place, forced me to make more space, and spend more time and attention to interactions with persons who were most radically different in my view.
But while doing this, I far from gained more insight into the motives, expectations and ideals of those others, nor did I knew more about what these people with a severe intellectual or multiple disability really wanted. As a result, the growing doubt, insecurity, confusion, fascination and unease made me feel obliged to raise awareness amongst policymakers about the inerasable and unknowable character of the otherness of people with a severe intellectual disability-at the same time emphasizing the relational aspects of this otherness.

Here, Waldenfels (2010) is helpful again. In his responsive ethics, we can try to relate to the other in a fitting way, if we recognize that our (initial) response to him undeniably refers to something about ourselves in relation to this person. What does my doubt, confusion, fascination, et cetera tell us about who I am, how I look, how I live-and about the durability thereof? Moreover, how do these ways in which I bring order and attach meaning to my perceptions, experiences and emotions relate to the possibilities I see for contact with these fellow human beings?

In my opinion, we should try to find answers to questions like these, if we really want to make more space for the otherness of people with severe intellectual or multiple disabilities, and if we want to counteract exclusion in a broader sense-in everyday life as well as in policy documents. To what extent are we providing space for inerasable, unknowable, confusing, provocative, and prickly otherness when we try to include everybody on the basis of mutual similarities? Additionally, what and who do we still exclude, even if we strive for full-fledged inclusion?

\section{A Scramble Around the Pulpit}

Doortje Kal: Here I completely agree with you: our response to the strange other does indeed refer to something about ourselves, our order, our meaning. This made me think about the metaphor of the musical chairs with only one chair-a pulpit-from the Dutch sociologist and philosopher Harry Kunneman (1996). Everyone wants to occupy the pulpit as long as possible, thereby forcing his way of looking, thinking and speaking-his interpretation-onto the others. Each discourse however, excludes alternative logics and ways of expressing oneself; hence there is always a scramble around the pulpit. Some people however, do not dispose of a language that is appropriate for the pulpit; they use an inappropriate idiom in the view of others. Therefore, they have no access to the pulpit.

Kunneman points out that Lyotard (1988) coined the word contravenity for this situation of aphasia. Lyotard makes an appeal to give voice to the injustice that cannot be articulated within the confines of a dominant discourse. I think that you tried to respond to this appeal in your dissertation-without knowing exactly, or even by a long way, what/which injustice the people involved would like to address. 


\section{Responsive Trust}

Gustaaf Bos: Ah, this metaphor is very helpful, thank you. According to Waldenfels, our efforts to community and connectedness should not be justified by the starting point of equality and/or bridgeability, but rather by the recognition of relational otherness. Responsive trust is a crucial concept here; the conviction that we can do justice to a confusing other even though we will never be able to give a complete, adequate and definite response to his demands. How to develop and shape this trustful responsive attitude in the best possible-i.e. the most righteous - way, is in my view particularly dependant on an ongoing dialogue between the people involved. Bearing in mind of course, that the other might not be able to express himself in your preferred communicational style-and vice versa.

Doortje Kal: I totally agree with the previous. You nicely summarized that I hope that deconstruction will lead to further reflection on existing exclusionary structures. As I mentioned before, in my dissertation I talk about suspension when it comes to this; suspension in order to find out how hospitality might be meaningful for the 'strange other', a person whose movements in our society (which is dominated by economic performance) do not go without saying. Subsequently, in my view, this suspension should also concern reflections on the conceptualisation and implementation of inclusion, participation or citizenship ideals. Applied to your research context: how can we prevent these concepts from passing by the radical otherness of people with a severe intellectual and/or multiple disability?

As you know, for policymakers, thinking in terms of equality and citizenship has an emancipatory background; after all there was a time that we thought that people who were different were best off in forests or dunes, that our society could (or needed) not harbour these 'deviants'. I sincerely think that it is important to recognize that many 'deviants' share ideals like autonomy, participation in mainstream society, and belonging with you and me. That is why I think it is unjust of you to dismiss our government policy at this point so firmly. That the conditions for the implementation of this policy are created abominably, or even reduced, is another issue.

Gustaaf Bos: For the record: I only criticize and reject the dominant policy focus on equality and equivalence when it comes to people with a severe intellectual and/or multiple disability.

\section{A Person is Never Strange on His Own: An Interpersonal or Societal Approach?}

Doortje Kal: That being said, I do agree with the question you raise about the exact benefits of the deinstitutionalization policy, or even the reversed integration policy, for people with severe or multiple disabilities.

You demonstrate how very different many people in reversed integration settings are-and how this other- ness confuses you. A cumulating doubt, you write, about everything you had regarded as self-evident, forced itself upon you. As a matter of fact, this is exactly the aim of suspension and deconstruction: reflection on the/your/my/our normality, which does not make space for the abnormal. But, you say, I could not find out-no matter how hard I tried-what would help the people involved.

However, besides the inerasable and unknowable character of this otherness, you also stress its relational makeup. The other is so different, so dissimilar compared to me (and my singularity, my familiarity). In Waldenfels' vocabulary: we are alien to each other due to each other; a person is never strange on his own. The perceived otherness always refers back to the perceiver as well.

I think that one of the main differences between us is that you-in line with Waldenfels-deploy this reflection very individually, whereas I do this with a rather societal scope. You thoroughly reflect upon the meanings that 'normal' individuals attach to the confrontation with so much otherness: people who mutilate themselves and others, who must be protected against themselves, tied up, medically sedated, isolated-perhaps even more so in reversed integration settings than in the total institutions of the past (because of the presence of 'normal' others).

Waldenfels' responsive ethics suggests that we can only begin to relate to a strange other if we recognize that our response to him undeniably says something about ourselves in relation to the other. You state that we have to be aware of this if we really intend to make space for the otherness of the other, and thus want to fight exclusion. I agree with you on this. At the same time, I want to stress that you and I are also part of a world which co-shapes us, and which we (are trying to) co-shape towards a world, a society that both recognizes and welcomes dissimilarity, no matter how complicated the consequences-consequences I also draw attention to in my work (see Kal, 2012). All this based on a responsive trust-and this is where we meet again - that a confusing other should not to be avoided but accepted.

Throughout my work, I never hide the fact that a 'normal' person might get hurt when he enters foreign territories, when he literally alienates himself. It is evident that normality cannot stay the same when encountered with otherness.

As you well know, I was quite involved with To Flourish, the dissertation of the Dutch psychologist Janny Beernink-Wissink (2015). Just like your dissertation, hers is about people with a severe intellectual disability, as well as serious behavioural problems. The pearl of her dissertation is the description of a radical change in the life of Anja, who from an existence dominated by a regime of safety (you call this 'the focus on what may go wrong', Bos, 2016, p. 168) came to live a flourishing life due to the interventions of Beernink as a behavioural therapist. Just like you, Beernink writes critically about the dominant care system and arrangements. 
In the end, she thinks, Martha Nussbaum's Capability approach can also be meaningful for people with severe disabilities, precisely because this approach consequently connects individual capabilities to the context (i.e. external capabilities, Nussbaum, 2006). Beernink illustrates how a meagre institutional environment in Anja's case leads to serious behavioural problems, which in turn resulted in deprivation of freedom, leading to even more behavioural problems, et cetera.

In your fifth chapter you also sharply analyse how the culture of an institution (i.e. system) colonizes the lifeworld of both original and new residents (and indeed yours as a researcher), and undermines the 'capabilities' of everyone involved. Furthermore, you, unlike Beernink, put more emphasis on the necessity of reflection-on yourself as a researcher, stakeholder, 'normal person' in that abnormal context. What does that add to what we know?

I think that both of your stories are necessary. On the one hand it is good to stress Beernink's effort to let people flourish (more)-with an eye for dilemmas and difficulties. On the other hand, it is good that you (sometimes rather extensively) identify and give thought to what it does to a 'normal human being' to be confronted with so much otherness, pain and sorrow; how we tend to flee, to avoid all of this.

I think that the recognition of difference, dissimilarity, leads to the recognition that not everything can be bridged, but certainly a part is bridgeable, connectable. That is something you illustrate again and again very nicely, for example where you describe your encounter with Betsy (Bos, 2016, p. 198).

\section{Making Space for Encounter by Moving Backwards}

Gustaaf Bos: I totally agree with you when you say that it is possible to connect the own and the alien. However, with this the otherness of the other is not bridged! Inspired by Waldenfels $(2004,2011)$, I argue in my dissertation that there is an abundance of options between self and other, but that with that the other is still not known. At most-and this often is very valuable!-something happens in an interaction between self and other.

With regard to encounters with people with a severe intellectual and/or multiple disability, the crux of the matter is that participants without disabilities are responsible for the content of the interaction. That is, the latter determine in most cases what happens; success or failure depends on their efforts, their voices. Their perspectives are decisive because the perspectives of the participants with severe disabilities remain largely unknown and because the balance of power between them is inevitably skewed. In my view, there has to be a lot more awareness about this, because nowadays we think and quite often say that our efforts are in line with what people with severe disabilities want, while in many cases we do not know what they wish for and/or cannot satisfy what we think their needs are. More than anything, we interpret what they want, basing their life and the shap- ing of it on our values, capabilities and limitations. This might be painful and difficult to acknowledge, but in my view this is what it is.

Precisely this inerasable difference had to be the starting point for us to think about, and work towards more space for otherness. This space might be in staying with the other despite not knowing. In my dissertation, I illustrate that working on this space can be done through humour, playfulness, listening, sensing, and without (too many) words. Making space is attending to the personal (stories) while interacting.

Waldenfels (2010) states that a (policy) starting point from which everybody is-or should be-equal, mistakenly neglects that in human interactions and relations, there is never a 'ready-made we'; every family, population group, congregation, class and community is a 'broken we' at best. He warns that the denying of this communal brokenness might function as a fertile breeding ground for a tyrannical societal system that does not tolerate deviation. Therefore, when we perceive something that (or someone who) is strange to us, we should avoid treating this a priori as a problem to be solved, but rather as a stimulus which keeps waking us from the sleep of normalisation (see also Waldenfels, 2011, p. 164).

That the way we cope with interpersonal differences-as an inevitable consequence of the unknowability of the otherness of another person-will always be imperfect and will always chafe, does not mean that we might as well do nothing. On the contrary: recognizing the brokenness of our efforts forces us into an ongoing rethinking and reflection. Hence, the insufficiency we experience when trying to do justice to another person is the driving force behind a permanent searching, responsiveethical attitude (see Irigaray, 1974).

Of course, the fundamental unknowability of the other's perspective applies to human relations in general, but it becomes extra apparent in relation to people with whom we cannot negotiate verbally about meaningswhich is by far the most common way of sharing perspectives in our society. If we, in spite of this, act as if we fully understand such a non-speaking other-and literally try to speak in his place-we will figuratively step on his toes.

According to Waldenfels, there is only one just way to speak for another person, and that is to take a step back, creating space for the other through suspension of our ideas, our ways, our preferences-and in this case our very verbal and cognitive drive. From this perspective, the space for encountering the other only opens up if we are willing to move backwards. Between our bodies; that is where it has to happen. However, I can only make it happen there when I realise that the creation and conditions of this space depend on my willingness and ability to renounce a mainly verbal and cognitive approach to communication; to suspend my tendency to immediately attach meaning to what I perceive.

As far as I am concerned this is a big challenge: to what extent are we able to connect with each other in 
a meaningful way and also with satisfaction, without a dominance of verbality and cognition? How can we relate to each other and to people with severe intellectual and/or multiple disabilities if we omit words? What will happen to us if we do? Which barriers will we face, but also: which opportunities will we discover? And what can we learn about/from such non-speaking others, about ourselves, and especially about ourselves in relation to these others-when we do not automatically start to talk in a mutual encounter, but consider how we can respond best to the way they present themselves to us?

\section{A Re-Evaluation of Dependency, Vulnerability and Solidarity}

I suspect that we will start to think in a different, more small-scale way about inclusion and participation if we take people with a severe intellectual and/or multiple disability-the most vulnerable, least articulate, least heard and therefore least understood-as a reference point. And I propose wholeheartedly that we do this for a change!

On the fringes of existing (policy) narratives and practices, we should introduce another story, another approach. It goes without saying that I fully back your focus on the societal responsibility to make space, but in my view this starts with a readiness to get to know one another on an interpersonal level-human to human. Too often, I miss the appreciation of the necessity of personal engagement and the involvement of everyone's individual ethics in contemporary thinking and debates on inclusion, participation and citizenship.

Do not forget that I, with my dissertation, wrote a critique based on the personal, situational and temporal stories from people involved in reversed integration settings. For most people to whom I spoke between 2010 and 2013, the lack of space for otherness was a concrete central issue. I do not claim that my findings are generalizable, but I do try, on the basis of these personally, situationally and temporally dependant narratives, to invigorate the dialogue about the precarious position of difference in the grand narrative of inclusion and participation.

I most certainly do not do this to dismiss the last twenty-five years' government policy without question. However, I do think that in the year 2016 the said policy still pays unjustifiably little attention to the unknowability of the perspectives of people who cannot speak (for themselves)-and subsequently to our responsibility, as individuals, care institutions, policymakers, and society as a whole, to create relational space for them. Space of encounter, in the words of the Dutch ethicist Herman Meininger (2013). Policymakers appear to be blind to the fact that in order to try to respond adequately to the unarticulated demands of others, all parties need to be open-minded, attentive, and ready to slow down or go the extra mile.

The big question, then, is which shared storylineone that is adjusted to the personal characteristics of all protagonists and to contextual features-would get us involved in meaningful encounters with people whom we might try to evade at first glance. A strong focus on autonomy and self-determination misses the point here (see Reinders, 2008, 2010). It would be better to try to bring people (with and without disability) together, and connect them with each other through a re-valuation of dependency, vulnerability and solidarity-something you advocate for in your work too. In this encounter, the personal stories of the most vulnerable people should take a central role; the other participants should relate their stories to these. That is not to say that the personal narratives of the people who want to get acquainted and connected with the vulnerable protagonists, should not be shared; they might inspire other people to do the same thing (see Bos, 2013).

Much listening to, and moving with, the other is needed; much imagination and empathy-in order to prevent us from automatically (and a priori) interpreting these stories through the lens of dominant ideals, or current policy narratives. If we do so, we will continuously be provoked to think in new, critical ways about existing orders of normality and deviation (see Kristeva, 1991; Meininger, 2008, 2013). Subsequently, what might happen in the encounter with another, will never be fully predictable nor completely up to us.

Doortje Kal: There was a time that I thought (and said) that people with a psychiatric background were an interesting point of reference to me, because for them contravenity - not being able to verbalize what is going on, because the words of the others are not theirsis such an influential phenomenon. But one could also claim that people with mild intellectual disabilities fall between two stools, because they belong nowhere due to that label 'mild'. And one could take an even broader scope, by saying that in our society as a whole the space for vulnerability is waning.

However, if people do not want to be reduced to their vulnerability and want to get a chance to flourish in what they are good at, this should not result in an increasing taboo of vulnerability-something that seems to be the case nowadays. This is, however, putting the cart before the horse; only in a society with space for vulnerability, can people be truly empowered, to use a popular idiom.

I heartily support your appeal to give also-and more often-a voice to the unheard and inarticulate. Besides, you think the whole movement for inclusion could learn something from that. Maybe you can elaborate a little on that?

\section{1. 'Listening Out' Personal Stories of Inarticulate Protagonists}

Gustaaf Bos: Well, I think that everyone who supports or advocates inclusion, participation and citizenship could learn a lot from what happens in encounters with persons with a severe intellectual and/or multiple disability. They could also learn a lot from the aforementioned 
themes-such as dependency and vulnerability-which are pivotal in their life and that of their relatives.

In summary, trying to find out what is good and important in the life of what might be the most vulnerable, most marginalized people of our society not only demands sharp eyes and sensitive ears, but also a lot of patience, time, perseverance, engagement, trust and the ability to suspend judgement. Put in another way, it demands our willingness and ability to listen out the personal stories of inarticulate protagonists, without foreknowledge about details and storyline. That is both exciting and challenging for many of us, especially since we tend to have a preferred and dominant storyline in mind. How do we approach this area of tension?

Doortje Kal: At the same time, this does not mean that I find community projects that encourage marginalized people (with mild disabilities), such as We are here [We zijn er] unworthy of our support ${ }^{3}$. I have underlined this before: in my view it is not about either/or, but about and/and! There is no final answer to these questions. How do we make fair policies and equitable institutions, and how do we make sure that the work is right and has positive results? The murkier the questions, the more important the moral quest for answers (see Kunneman, 2013).

How do we struggle with dignity, and how do we accomplish informative friction? In swampy lowlands (see Schön, 1987) it is sometimes hard to get, and stay, close to each other-and the two of us have experienced this in our discussions throughout the years. However, this is no reason to move exclusively on high grounds, or to avoid prickliness.

First of all, you confronted me with the work of Waldenfels. He underlines the relational aspect of being different-one is no other on one's own-once more. You especially made me think about the inevitable tension, arising when you stay with the other, the other to whom I almost unbearably differ, and from whom I perhaps would rather walk away because I feel incapable.

I hope that our never-to-be-abandoned quest for encounter, connection and inclusion-also, or especially, on the micro-level you have investigated-is of value; first for the people involved, and secondly the broader context (which I am a part of!). In Responding to otherness, you show encouraging examples of this. All in all, you strengthen me in advocating being different, in spite of the criticism I sometimes get for that categorization.

Gustaaf Bos: I am glad to hear that! Your open, virtually all-inclusive way of thinking encourages me to keep in mind the great effort, engagement and conviction of so many who pursue the citizenship ideal. Besides, you often remind me of the positive effects that thinking and working from a position of equality-a citizen in a democratic society-may have on an individual level. With reference to that, I find what you said about 'powerless purity' versus 'a feasible activity that may compromise and whereby one-for the benefit of results-may concede what one is challenging' quite helpful. Working on an ideal that contributes to a better place in our society for marginalized people-although it may sometimes yield the opposite of what you aim for-is preferable compared to doing nothing because it may sometimes yield the opposite of what you aim for.

Encounters with people with a severe intellectual and/or multiple disability are not a matter of perfection, but of relation; they consist of a personal intention to do right by and connect with the other. May the beautiful poem of an anonymous poet on the endpaper of Dutch ethicist Hans Reinders' Receiving the gift of friendship (Reinders, 2008) inspire many people to keep working for more of these spaces of encounter:

Blessed are you who take time to listen to difficult speech for you help us persevere until we are understood.

Blessed are you who walk with us in public spaces and ignore the stare of strangers, for we find havens of relaxation in your companionship.

Blessed are you who never bid us to 'hurry up', and more blessed are you who do not snatch our tasks from our hands to do them for us, for often we need time-rather than help.

Blessed are you who stand beside us as we enter new and untried ventures, for the delight we feel when we surprise you outweighs all the frustrating failures.

Blessed are you who ask for our help, for our greatest need is to be needed.

\section{Acknowledgments}

The authors wish to thank Paul van Trigt for his insightful comments on earlier versions of this text, and Audrey Wijnberg for carefully editing all our English attempts.

\section{Conflict of Interests}

The authors declare no conflict of interests.

\section{References}

Abma, T. A. (2006). The practice and politics of responsive evaluation. American Journal of Evaluation, 27(1), 31-43.

Beernink-Wissink, J. (2015). Floreren. Zoektocht naar goed leven voor mensen met een ernstige verstandelijke beperking en ernstige gedragsproblemen [To Flourish]. Delft: Eburon.

Bos, G. F. (2013). Gedachten over 'kwartiermaken'. In D. Kal, R. Post, \& J. P. Wilken (Eds.), Verder met kwartiermaken. Naar de verwelkoming van verschil (pp. 132-

\footnotetext{
${ }^{3}$ See www.stichtingdetoekomst.nl/wezijner/
} 
134). Amsterdam: Tobi Vroegh.

Bos, G. F. (2016). Antwoorden op andersheid. Over ontmoetingen tussen mensen met en zonder verstandelijke beperking in omgekeerde-integratiesettingen [Responding to otherness: About encounters between people with and without intellectual disabilities in 'reversed integration' settings]. Nieuwegein: EPC.

Boumans, J. (2013). Doortje Kals proefschrift als inspiratiebron. In D. Kal, R. Post, \& J. P. Wilken (Eds.), Verder met kwartiermaken. Naar de verwelkoming van verschil (pp. 170-173). Amsterdam: Tobi Vroegh.

Brons, R. (2014). Waardenwerk voor de strijdigheid van het bestaan. Waardenwerk, 57, 72-84.

Deleuze, G., \& Guattari, F. (1987). A thousand plateaus: Capitalism and schizophrenia. Minneapolis: University of Minnesota Press.

Derrida, J. (1998). Over gastvrijheid (R. Hofstede, Trans.). Amsterdam: Boom.

Irigaray, L. (1974). Speculum of the Other Woman (Gillian C. Gill, Trans.). Ithaca: Cornell University Press.

Jackson, A. Y., \& Mazzei, L. A. (2013). Plugging one text into another: Thinking with theory in qualitative research. Qualitative Inquiry, 19(4), 261-271.

Kal, D. (2001). Kwartiermaken. Werken aan ruimte voor mensen met een psychiatrische achtergrond ['Setting up camp': Preparing a welcome for people with a psychiatric background]. Amsterdam: Boom.

Kal, D. (2012). Kwartiermaken, creating space for otherness. In H. van Ewijk, J. van Eijken, \& H. Staatsen (Eds.), A good society is more than just a private affair. Citizenship based social work in practice. Studies in comparative social pedagogies and international social work and social policy (pp. 25-41). Bremen: EHV.

Kal, V. (2004). Jacques Derrida and Messianity. In M. Sarot \& W. Stoker (Eds.), Religion and the good life (pp. 213-229). Assen: Van Gorcum.

Kristeva, J. (1991). Strangers to ourselves. New York: Columbia University Press.

Kunneman, H. (1996). Van theemutscultuur naar walkman-ego. Contouren van postmoderne individualiteit. Amsterdam: Boom.

Kunneman, H. (2005). Voorbij het dikke-ik. Bouwstenen voor een kritisch humanisme. Amsterdam: SWP Humanistics University Press.

Kunneman, H. (2013). Kleine waarden en grote waarden. Normatieve professionalisering als politiek perspectief. Amsterdam: SWP Humanistics University Press.

Lévinas, E. (1969). Totality and infinity: An essay on exteriority. Pittsburgh: Duquesne University Press.

Lyotard, J.-F. (1988). The differend: Phrases in dispute. Minneapolis: University of Minnesota Press.

Meininger, H. P. (2008). The order of disturbance: Theological reflections on strangeness and strangers, and the inclusion of persons with intellectual disabilities in faith communities. Journal of Religion, Disability \& Health, 12(4), 347-364.

Meininger, H. P. (2013). Inclusion as heterotopia: Spaces of encounter between people with and without in- tellectual disability. Journal of Social Inclusion, 4(1), 24-44. Retrieved from https://josi.journals.griffith. edu.au/index.php/inclusion/article/view/252

Ministerie van WVC (1993). Onder anderen. Geestelijke gezondheid en geestelijke gezondheidszorg in maatschappelijk perspectief. Den Haag: Sdu Uitgeverij.

Nirje, B. (1969). The normalization principle and its human management implications. In R. Kugel \& W. Wolfensberger (Eds.), Changing patterns in residential services for the mentally retarded (pp. 19-23). Washington, D.C.: President's Committee on Mental Retardation.

Nussbaum, M. C. (2006). Frontiers of justice: Disability, nationality, species membership. Cambridge: The Belknap Press.

Reinders, H. S. (2008). Receiving the gift of friendship: Profound disability, theological anthropology, and ethics. Michigan/Cambridge, UK: Wm. B. Eerdmans Publishing Co.

Reinders, H. S. (2010). Geen leven zonder vriendschap. Over mensen met een ernstige beperking. Zoetermeer: Meinema.

RMO (2002). De handicap van de samenleving. Over mogelijkheden en beperkingen van community care (No. 25). Den Haag: Raad voor Maatschappelijke Ontwikkeling.

RVZ (2002). Samen leven in de samenleving. Community care en community living (No. 02/09). Zoetermeer: Raad voor de Volksgezondheid en Zorg.

Schön, D. A. (1987). Educating the reflective practitioner. San Fransisco, CA: Jossey-Bass.

Smaling, A. (2008). Dialoog en empathie in de methodologie. Amsterdam: SWP Humanistics University Press.

Taskforce Vermaatschappelijking Geestelijke Gezondheidszorg (2002). Erbij horen. Amsterdam.

Tweede Kamer. (1995). De perken te buiten. Meerjarenprogramma intersectoraal gehandicaptenbeleid 1995-1998 (No. 24170). Den Haag: Sdu Uitgeverij.

Waldenfels, B. (1990). Der Stachel des Fremden. Frankfurt am Main: Suhrkamp.

Waldenfels, B. (2004). Bodily experience between selfhood and otherness. Phenomenology and the Cognitive Sciences, 3, 235-248.

Waldenfels, B. (2010). Response and trust: Some aspects of responsive ethics. New York: Stony Brook State University. Retrieved from https://www.youtube.com/ watch?v=t6iOsQ_hi94

Waldenfels, B. (2011). In place of the other. Continental Philosophy Review, 44, 151-164.

Walmsley, J. (2001). Normalisation, emancipatory research and learning disability. Disability and Society, 16(2), 187-205.

Walmsley, J. (2004). Inclusive learning disability research: The (non-disabled) researcher's role. British Journal of Learning Disabilities, 32(2), 65-71.

Wolfensberger, W. (1983). Social role valorization: A proposed new term for the principle of normalization. Mental Retardation, 21(6), 234-239. 
Young, I. M. (1997). Asymmetrical reciprocity: On moral respect, wonder, and enlarged thought. Constellations, 3(3), 340-363.

\section{About the Authors}

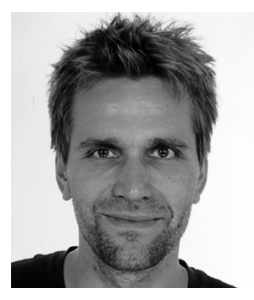

Gustaaf Bos (1982) received his Masters' Degree in Psychology in 2009 at the RUG University Groningen. Between 2010 and 2015 he conducted his PhD-research at the VU University Amsterdam on what happens in encounters between people with and without intellectual disabilities in 'reversed integration' settings. Since 2016 he has been working at the VU University Medical Centre on two projects regarding participation and experiential knowledge of people with an intellectual disability. Moreover, he is involved in the preparation of a pilot project that facilitates and creates encounters between people with and without a severe intellectual and/or multiple disability or behavioural difficulties. The aim of this project is to make the latter more visible and to enlarge their social network.

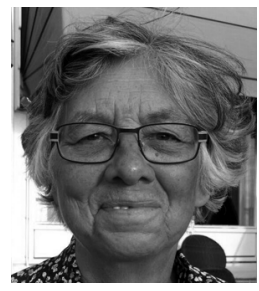

Doortje Kal (1948) was prevention worker Social Psychiatry between 1992 and 2002. She received her PhD at the University of Humanistic Studies on 'Setting up camp': Preparing a welcome for people with a psychiatric background [Kwartiermaken] in 2001. From 2011 until 2013 she was lector of 'Kwartiermaken' at the Utrecht University of Applied Sciences. Together with Gustaaf Bos and Jacqueline Kool she is in charge of the secretariat of the Dutch Researchers' platform 'Disability studies, inclusion, belonging'. In 2006 she published a German translation of her dissertation: 'Gastfreundschaft. Das niederländische Konzept Kwartiermaken gegen Ausgrenzung'. See for further information http://www.kwartiermaken.nl/english. 